\title{
Comunicação
}

[Communication]

\section{ELISA indireto para deteç̧ão de IgG antivírus da doença de Newcastle em soro de codorna}

\author{
[Indirect ELISA for the detection of IgG specific to Newcastle disease virus in quail serum] \\ D.D. Oliveira ${ }^{1}$, A.V. Folgueras-Flatschart ${ }^{2}$, R.B. Flatschart ${ }^{1}$, J.S. Resende ${ }^{1}$ \\ J.T. Abreu ${ }^{3}$, N.R.S. Martins ${ }^{1 *}$ \\ ${ }^{1}$ Escola de Veterinária - UFMG \\ Caixa Postal 567 \\ 30123-970 - Belo Horizonte, MG \\ ${ }^{2}$ UNIPAC - Ipatinga, MG \\ ${ }^{3}$ PUC-Minas
}

Com o crescimento do número de criações comerciais de codornas, é presumível que haja aumento na ocorrência de condições que promovem transtornos sanitários, com um maior número de eventuais aves portadoras de agentes infectocontagiosos. Desta forma, o risco de ocorrência de doença nas regiões de maior concentração de aves. A monitoração de plantéis avícolas para o risco de doença de Newcastle (DN) é uma exigência do Programa Nacional de Sanidade Avícola.

Dados de literatura confirmam a susceptibilidade das codornas a diversos agentes infectocontagiosos, entre eles o NDV (Alexander, 2003). O diagnóstico de situação, a vigilância e a triagem sorológica para $\mathrm{DN}$ na coturnicultura, não têm sido implantados por falta de um ensaio com sensibilidade e automação. Há deficiência de publicações sobre a epidemiologia da ND, além de outras doenças, em codornas japonesas. Fatos relativamente freqüentes na avicultura industrial são as falhas de medidas de biossegurança, como a proximidade entre galpões de galinhas e de codornas, muitas vezes de idades e procedências múltiplas, situação esta que pode estar reciclando vários patógenos.

O teste de inibição da hemaglutinação (IH) é considerado teste padrão (Miers et al., 1994) na

Recebido em 27 de abril de 2007

Aceito em 31 de outubro de 2007

*Autor para correspondência (corresponding author)

E-mail: rodrigo@vet.ufmg.br detecção de anticorpos anti-NDV. Porém, o ELISA é o teste sorológico mais utilizado em avicultura para outras etiologias por sua sensibilidade, especificidade e rapidez (Santos e Silva, 2000). A inexistência de um teste de ELISA específico para codorna tem motivado os laboratórios de diagnóstico a utilizarem os kits para ensaio exclusivo com soro de galinha. Considerando-se que o diagnóstico sorológico em codornas tem sido efetuado com procedimentos técnicos descritos para galinhas, sem a devida validação e que não há na atualidade um ELISA especificamente desenvolvido para codornas, o objetivo deste trabalho foi padronizar um ELISA indireto para a detecção de $\operatorname{IgG}$ específicas para NDV, em codornas japonesas (Coturnix japonica).

Para a purificação de IgG do soro de codornas (Bhanushali et al., 1994), foram coletados $10 \mathrm{ml} \mathrm{de}$ soro de codorna diluído a 1:5 em tampão acetato, com acréscimo de ácido caprílico até a concentração de $25 \mu \mathrm{l} / \mathrm{ml}$ de soro, mantido sob agitação overnight a $4^{\circ} \mathrm{C}$. O sobrenadante foi removido, clarificado por centrifugação a $10.000 \times \mathrm{xg} / 30 \mathrm{~min} / 4^{\circ} \mathrm{C}^{1}$, filtrado em membrana $0,45 \mu \mathrm{m}^{2}$ e misturado com PBS pH 7,2 na proporção 1:10. Ao sobrenadante adicionou-se solução saturada e tamponada de sulfato de amônio, gota a gota, em banho de gelo, sob homogeneização constante até concentração final de $36 \%$ de saturação. A fração insolúvel foi precipitada por centrifugação $\left(10.000 \times \mathrm{xg} / 30 \mathrm{~min} / 4^{\circ} \mathrm{C}\right)$ e o pellet foi ressuspenso com PBS pH 7,2 estéril (1:100 do

${ }^{1}$ Sorval RC-5B, Du Pont - EUA.

${ }^{2}$ Millipore - EUA. 
volume de soro original) e dialisado. Os extratos com IgG foram armazenados a $4^{\circ} \mathrm{C}$ sem conservantes biológicos. A dosagem de proteína de cada amostra foi feita pelo método de Lowry, segundo o manual do fabricante ${ }^{3}$. Para a verificação da pureza das amostras de IgG, foi feita eletroforese em PAGE (Alfenas, 1998). A produção de IgG de camundongo anti-IgG de codorna foi obtida em fêmeas de camundongos Balb/c, com seis semanas de idade, inoculadas com $100 \mu \mathrm{g}$ de IgG purificada (Harlow e Lane, 1988).

O western blot foi empregado para a determinação da especificidade do anticorpo secundário anti-IgG de codorna produzido nos camundongos. A IgG de camundongo anti-IgG de codorna foi usada na diluição 1:500, conforme titulação em ELISA com IgG de galinha e detectada com anti-IgG de camundongo conjugada com fosfatase alcalina ${ }^{3}$, tampão AP (Tris $\mathrm{HCl} \mathrm{pH} 9,5, \mathrm{NaCl}, \mathrm{MgCl}_{2}$ ), $\mathrm{NBT}^{3}$ e $\mathrm{BCIP}^{3}$ (Makkay et al., 1999).

Os soros positivos foram produzidos em 30 codornas vacinadas por via ocular com vacina viva comercial de NDV (aproximadamente $10^{5,5} \mathrm{DIE}_{50} /$ ave) e inoculadas 20 dias após com vacina inativada em emulsão oleosa com adjuvante completo de Freund. Os soros foram coletados 21 dias após a segunda aplicação. Os 30 soros negativos foram coletados de codornas de duas semanas de idade não vacinadas, oriundas de matrizes também não vacinadas e mantidas em ambiente separado até a coleta. Os soros coletados foram testados por IH (Beard, 1980). Os títulos dos soros foram determinados em média geométrica (GMT).

O ELISA indireto para a detecção de $\operatorname{IgG}$ de codorna contra o NDV, com o uso de anticorpo secundário produzido (IgG de camundongo antiIgG de codorna) e conjugado IgG de cabra antiIgG de camundongo foi padronizado por titulação em bloco. As microplacas de ELISA $^{3}$ foram sensibilizadas com $100 \mu \mathrm{l}$ de diluições duplicadas seriadas do NDV em tampão carbonato-bicarbonato $\mathrm{pH}$ 9,6 e incubadas por $2 \mathrm{~h}$ a $37^{\circ} \mathrm{C}$. O bloqueio foi feito com $50 \mu \mathrm{l}$ de tampão de bloqueio (leite em pó desnatado 3\% em PBS) incubado por $1 \mathrm{~h}$ a $37^{\circ} \mathrm{C}$. As diluições

${ }^{3}$ Sigma - EUA. dos soros positivos e negativos de codorna para NDV foram 1:50 e 1:100. Diluições seriadas, a partir de 1:1000, do anticorpo secundário produzido em camundongo anti-IgG de codorna e, na etapa seguinte, do conjugado - IgG de cabra anti-IgG de camundongo conjugado com fosfatase alcalina $^{3}$, a 1:500, 1:1.000, 1:5.000, $1: 10.000$ e 1:30.000, foram incubadas por $1 \mathrm{~h} \mathrm{a}$ $37^{\circ} \mathrm{C}$. Após a lavagem, o substrato $\rho N P P$ a $1 \mathrm{mg} / \mathrm{ml}$, em tampão de dietanolamina com $\mathrm{MgCl}_{2} \mathrm{pH} 8^{3}$, foi adicionado $(50 \mu \mathrm{l})$ e as microplacas incubadas por $30 \mathrm{~min}$ a $37^{\circ} \mathrm{C}$. A leitura das densidades ópticas foi em espectrofotômetro com filtro de $405 \mathrm{~nm}$. Entre cada etapa as microplacas foram lavadas três vezes com PBS Tween 0,05\% (Sahle et al, 2002). Como critério para a seleção das concentrações ideais, as diluições que apresentaram a maior diferença em densidade óptica (DO) entre os soros positivos e negativos foram escolhidas. Para evitar a variação intermicroplacas dos resultados, cada valor de absorvância foi multiplicado por um fator de correção ( $\mathrm{f}=1 /$ média das leituras dos soros controle positivo) determinado para cada microplaca (Folgueras, 1998). A análise estatística dos resultados foi feita pelo método Two-graph receiver operating characteristic (TG-ROC) (Greiner, 1995). Houve maior pureza para IgG purificada do soro de codornas que IgG purificada a partir da gema de ovos de codornas. Essa avaliação foi determinada pela demonstração em eletroforese, de banda equivalente apenas à $\mathrm{IgG}$ no soro, mas com bandas contaminantes na gema (Fig. 1). Demonstrou-se, por western blotting a resposta humoral específica para IgG de codorna no soro dos camundongos (Fig. 1).

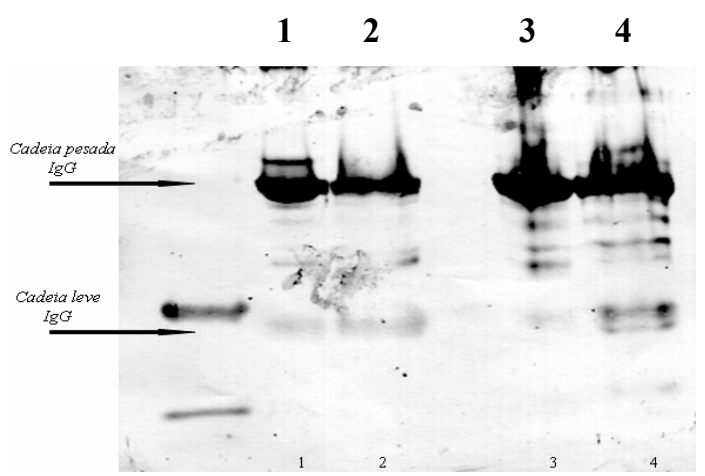

Figura 1. Western blotting. IgG purificada do soro (1 e 2) e IgG purificada da gema de ovos (3 e 4) de codornas japonesas, reveladas com $\operatorname{IgG}$ de camundongo anti-IgG de codorna e coradas com NBT 
e BCIP. Notar o maior número de bandas e menor pureza do extrato de $\mathrm{IgG}$ de gema.

No $\mathrm{IH}$, os títulos, expressos em GMT, foram 315,17 e $\leq 2$, nas codornas vacinadas e não vacinadas, respectivamente, semelhante aos resultados observados por Alexander (2003) em galinhas. Os soros de codornas vacinadas (positivos) e não vacinadas (negativos) por $\mathrm{IH}$, foram mais bem avaliados em ELISA quando diluídos a 1:50 e utilizando-se $30 \mu \mathrm{g} / \mathrm{ml}$ de NDV na fase sólida. $\mathrm{O}$ anticorpo secundário e $\mathrm{o}$ conjugado (IgG de cabra anti-IgG de camundongo) foram melhor discriminantes quando diluídos a 1:5000. Os resultados do ELISA e a média geométrica dos títulos encontrados no IH para os soros positivos e negativos são apresentados na Tab. 1. Com os valores de absorvância de cada soro corrigidos pelo fator de correção (f), foi estabelecido o ponto de corte do ELISA por meio do TG-ROC e análise de sensibilidade e especificidade para a melhor discriminação entre positivos e negativos.

Tabela 1. Inibição da hemaglutinação (IH) e ELISA para IgG de codorna em soros de codornas vacinadas ou não para NDV

\begin{tabular}{cccc}
\hline Codornas & IH $(+)$ & IH $(-)$ & ELISA $^{2}$ \\
\hline Vacinadas & 30 & 0 & 0,808 \\
Não vacinadas & 0 & 30 & 0,288 \\
\hline
\end{tabular}

${ }^{1}$ Vacinação ocular $(30 \mu \mathrm{l})$ com La Sota $10^{5,5}$ DIE50/ave e inoculação intramuscular com $0,1 \mathrm{ml}$ da mesma vacina em emulsão oleosa com adjuvante completo de Freund.

${ }^{2}$ Absorvância média.

Houve correlação entre os dois testes, e o ELISA pode ser recomendado, para utilização em codornas japonesas, após inoculação com NDV vacinal. Não há resultados descritos para codornas na literatura, embora em galinhas resultados semelhantes foram descritos (Das et al. 1997; Bozorghmehrifard e Mayahi, 2000). A correlação entre os testes valida o ELISA, que oferece a vantagem de maior sensibilidade, padronização e operacionalidade. A maior sensibilidade é especialmente importante na detecção da resposta imune precoce, cujos resultados possibilitam a monitoração mais eficiente dos plantéis industriais. $\mathrm{O}$ desenvolvimento de reagente específico para IgG de codorna mostrou-se uma solução eficiente, uma vez que não existe um conjugado anti-IgG de codorna comercial, e decisivo para a padronização do ELISA específico para codorna. Os resultados de especificidade e sensibilidade do ELISA foram equivalentes em comparação com o teste-ouro (IH). O ELISA indireto para anticorpos da classe IgG de codorna específicos para NDV pode ser recomendado como técnica de triagem e diagnóstico da DN em codornas.

Palavras-chave: codorna japonesa, ELISA, IgG, doença de Newcastle

\begin{abstract}
An indirect ELISA for the detection of japanese quail IgG specific to Newcastle disease virus (NDV) was developed. The secondary anti-quail IgG was produced in Balb/c mice, by inoculating Freund's complete adjuvant emulsified japanese quail-IgG extract. The purification of IgG was achieved using the caprilic acid method. The ELISA was compared to the haemagglutination-inhibition (HI) test for antibodies to NDV. ELISA cut-off point was established through TG-ROC analysis. Total correlation was observed between the ELISA and the HI, being the ELISA efficient in the identification of positive and negative sera, with high sensitivity and specificity (100\%). These results validate the use of the indirect ELISA as an alternative for the detection of $N D V$-specific IgG in japanese quail sera, with the advantage of high sensitivity and automation.
\end{abstract}

Keywords: japanse quail, ELISA, IgG, newcastle disease

\section{REFERÊNCIAS BIBLIOGRÁFICAS}

ALEXANDER, D.J. Newcastle Disease, other avian Paramyxoviruses, and pneumovirus infections. In: SAIF, Y.M. (Ed.). Diseases of Poultry. 11.ed. Ames: Iowa State University, 2003. p.63-100. 
ALFENAS, A.C. (Ed). Eletroforese de isoenzimas e proteínas afins: fundamentos e aplicações em plantas e microrganismos. Viçosa: UFV, 1998.

BEARD, C.W. Serologic procedures. In: HITCHNER, S.B. (Ed). Isolation and identification of avian pathogens. 2.ed. Texas: Creative Printing Company, 1980. p.129-135.

BHANUSHALI, J.K.; GILBERT, J.M.; McDOUGALD, L.R. Simple method to purify chicken immunoglobulin G. Poult. Sci., v.73, p.7-9, 1994.

BOZORGHMEHRIFARD, M.H.; MAYAHI, M. Comparison of enzyme linked-immunosorbent assay and haemagglutination inhibition test for the detection of antibodies against Newcastle disease vaccine in broiler chicks. Ind. J. Anim. Sci., v.70, p.39-40, 2000.

DAS, S.; SHARMA, K.; SARMAH, D.K.; KALITA, N. Correlation of HI and ELISA tests for detection of Newcastle disease virus antibodies. Indian J. Anim. Sci., v.67, p.286-287, 1997.

FOLGUERAS, A.V. Desenvolvimento $e$ padronização de teste imunoenzimático (ELISA) para a detecção de anticorpos contra o herpesvírus bovino. 1998. 70f. Dissertação (Mestrado) Instituto de Ciências Biológicas, Universidade Federal Minas Gerais, Belo Horizonte.
GREINER, M. Two-graph receiver operating characteristic (TG-ROC): a Microsoft-EXCEL template for the selection of cut-off values in diagnostic tests. J. Immunol. Methods. n.185, p.145-146, 1995.

HARLOW, E.; LANE, D. Antibodies: a laboratory manual. New York: Cold Spring Harbor, 1988.

MAKKAY, A.; KRELL, P.J.; NAGY, E. Antibody detection-based differential ELISA for NDVinfected or vaccinated chickens versus NDV HNsubunit vaccinated chickens. Vet. Microb., v.66, p.209-222, 1999.

MIERS, L.A.; BANKOWSKI, R.A.; ZEE, Y.C. Optimizing the Enzyme-linked Immunosorbent Assay for evaluating immunity of chickens to Newcastle disease. Avian Dis., v.27, p.1112-1125, 1994.

SAHLE, M; BURGESS, G.W. Development of solid phase antigen for indirect ELISA for the detection of specific antibody responses to infection with Newcastle disease virus. Onderstepoort J. Vet. Res., v.69, p.237-242, 2002.

SANTOS, C.H.C.; SILVA, E.N. Métodos de diagnósticos laboratoriais microbiológicos e sorológicos. In: BERCHIERI JUNIOR, A.; MACARI, M. (Eds.). Doenças das aves. Campinas: FACTA, 2000. p.171-182. 